\title{
Metallurgical and Material Properties of Castings Manufactured from Stainless Steel G-X4CrNi13-4 and G-X4CrNiCu13-4
}

Josef Odehnal, Stanislav Brotánek

Technical Department, PILSEN STEEL s.r.o., josef.odehnal@pilsensteel.cz

This article presents the metallurgical and material properties of castings from stainless steel G-X4CrNi13-4 and G-X4CrNiCu13-4, which can be obtained under the conditions of the Foundry shop of PILSEN STEEL s.r.o. The article mentions furnace units of primary and secondary metallurgy in which the stated quality steel is produced. By way of illustration of achieved properties of melt, the heat analyses and micro-purity of steel are shown. Mechanical properties of steel are represented in well arranged graphs showing achieved values of the yield point, tensile strength, and impact energy at various temperatures, such as for example: 20, -10, -20, -30, $-40,-50$ a $-60^{\circ} \mathrm{C}$. By way of illustration, there are figures of the castings most frequently produced from stainless steel in the Foundry shop of PILSEN STEEL s.r.o. In the end, the article points out what effect has micro-purity of steel on the value of impact energy.

Keywords: metallurgy, stainless steel G-X4CrNi13-4, micro-purity of steel, mechanical properties, PILSEN STEEL s.r.o.

\section{References}

[1] STEFANESCU, D. M. (1970). Metals handbook: VOLUME 15 - Casting. 9th ed. Metals Park, Ohio: American Society for Metals, c1978-c1989, 948 - 957. ISBN 0-87170-007-7.

[2] ODEHNAL, J. (2012). Effect of metallurgy and casting technology on heavy steel castings quality. Ostrava, 2012, Diploma thesis. VŠB-TU Ostrava, FMMI, Department of Foundry.

[3] FRUEHAN, R. (2003). Casting volume: Historical aspects and key technologies. [Electronics Resource], 11. ed. Pittsburgh, Pa: AISE Steel Foundation, 2003. ISBN 0-930767-04-7.

[4] GHOSH, A. (2001). Secondary steelmaking: principles and applications. Boca Raton, Fla.: CRC Press, (c) 2001,322 s. ISBN 08-493-0264-1.

[5] FRUEHAN, R. The making, shaping, and treating of steel: Reffining of Stainless Steels. 11th ed. Pittsburgh, PA: AISE Steel Foundation, c1998-c1999. ISBN 0-930767-02-0.

[6] STAVEHAUG, L. (1970). Operational Experiences with the ASEA-SKF Ladle Furnace in Stainless Steelmaking. Modern Refining Techniques: Electric Furnace Proceedings. 1970.

[7] GREVILliUS, N., GEETE, P., KREY, T. (1970). Operational Experience of the ASEA-SKF Ladle Furnace process at Bofors Steelworks. Modern Refining Techniques: Electric Furnace Proceedings. 1970.

[8] CHUNG, S., SHIN, Y., YOON, Y. (2012). Flow Characteristics by Induction and Gas Stirring in ASEA-SKF Ladle. ISIJ International. 1992 (no. 12), 1287-1296.

[9] JONES, P. (2001). Degradation mechanisms of basic refractory materials during the secondary refining of stainless steel in VOD ladles. Heverlee (België), 2001. ISBN 90-5682-297-7. Doctoral theses. Katholieke Universiteit Leuven - Faculteit Toegepaste Wetenschappen Arenbergkasteel.

[10] Production of Stainless Steels: Part Three. Key to Metals: The World's Most Comprehensive Metals Database. 1999 - 2012.

[11] LO, K.H., SHEK, C.H., LAI, J.K.L. (2009). Recent developments in stainless steel. Materials Science and Engineering: R: Reports, Volume 65, Issues 4-6, 29 May 2009, Pages 39-104.

[12] ČUBAN, J., CALONIUS, O., PIETOLA, M., JERSÁK, J. (2011). Fatigue life and surface integrity measurements of EN S355J2 steel used in hydraulic components. Manufacturing technology. December 2011, Volume 11, Issue 11, Pages 5-11. ISSN 1213-2489.

[13] ROSENBERG, G., JUHÁR, L. (2012). Fatigue resistance of dual phase steels in presence of microstructural inhomogeneities. Manufacturing technology. December 2012, Volume 12, Issue 13, Pages 217-221. ISSN 1213-2489.

[14] ROSENBERG, G., SINAIOVÁ, I., JUHÁR, L. (2012). Influence of microstructural heterogeneities on capacity to absorb energy of dual-phase steels. Manufacturing technology. December 2012, Volume 12, Issue 13, Pages 222-227. ISSN 12132489.

[15] FERREÑO, D., ÁlVAREZ, J.A., RUIZ, E., MÉNDEZ, D., RODRÍGUEZ, L., HERNÁNDEZ, D. (2011). Failure analysis of a Pelton turbine manufactured in soft martensitic stainless steel casting. Engeneering Failure Analysis, Volume 18, Issue 1, January 2011, Pages 256-270. 